\title{
DEVELOPMENT OF JUNIOR HIGH SCHOOL EDUCATION PROFESSION IN THE EDUCATION SERVICE OF KUTAI BARAT REGENCY
}

\author{
Yuwono Catur Saputro, Lambang Subagiyo, Laili Komariyah \\ Universitas Mulawarman \\ yuwonocaturs@gmail.com
}

\begin{abstract}
This study aims to examine the development of the profession of junior high school educators in the Kutai Barat District Education Office which includes (1) planning the development process, (2) implementation of the development process and (3) development results. The method used in this research is descriptive qualitative which aims to produce data with a descriptive qualitative analysis that describes the state of the professional development of junior high school educators in the West Kutai District Education Office. Data collection in this study was done by participant observation or participant observation, documentation and interviews. The results showed that the development of the profession of junior high school educators in the West Kutai District Education Office at the planning stage had considered management elements with indicators of man, money, materials, machines, methods, marketing, and minutes. At the implementation stage of the development of the profession of junior high school educators in the West Kutai District Education Office also considers management elements with indicators of man, money, material, machines, methods, marketing, and minutes, in the form of socialization, training, in house training, workshoap and MGMP. And at the evaluation stage the results of the development of the profession of junior high school educators in the West Kutai District Education Office showed that of 320 junior high school educators as many as 95 people or $29.69 \%$ Group IV a and 13 people or $4.06 \%$ achieved Group IVb. Recommendations need to be held specifically for Classroom Action Research.
\end{abstract}

Keywords: Professional Development of Junior High School Teachers

\section{Pendahuluan}

$\begin{array}{cr}\text { Pesatnya } & \text { perkembangan ilmu } \\ \text { pengetahuan dan teknologi sangat }\end{array}$ mempengaruhi perkembangan kehidupan umat manusia. Setiap bangsa berlomba-lompa untuk meningkatkannya, sehingga kemajuan ilmu pengetahuan dan teknologi berkembang dengan pesat di segala bidang.

Negara Kesatuan Republik Indonesia sebagai salah satu di antara warga dunia ini juga tidak luput dari pesatnya perkembangan ilmu pengetahuan dan teknologi. Letak geografis Indonesia juga memudahkan masuknya budaya dan informasi ke dalam negeri. Derasnya arus budaya dan informasi dari luar di era globalisasi ini menimbulkan ada beberapa tuntutan yang harus segera mendapat perhatian serius dalam dunia pendidikan di antaranya adalah pentingnya sumber daya manusia yang berkualitas dan berdedikasi tinggi serta tersediannya jaringan informasi yang mampu mengakses segala kebutuhan terhadap pemenuhan kebutuhan pendidikan.

Pentingnya pendidikan ini sangat disadari oleh para pendiri Negara Kesatuan Republik Indonesia yang telah memiliki pemikiran luas dan komprehensif mengenai kehidupan bangsa Indonesia dalam kancah dunia yang selalu berubah. Pemikiran tersebut diwujudkan dalam Pembukaan UndangUndang Dasar Republik Indonesia Tahun 1945 (UUD 1945), yaitu bahwa "tujuan pembentukan Pemerintah Negara Indonesia adalah melindungi segenap bangsa Indonesia dan seluruh tumpah darah Indonesia dan untuk memajukan kesejahteraan umum, mencerdaskan kehidupan bangsa dan ikut melaksanakan ketertiban dunia yang berdasarkan kemerdekaan, perdamaian abadi dan keadilan sosial".

Tujuan nasional tersebut bisa dicapai antara lain dengan melalui penyelenggaraan pendidikan bagi seluruh bangsa Indonesia. Selanjutnya dalam UUD 1945 pada Pasal 31 dinyatakan bahwa : (1) Setiap warga negara berhak mendapatkan pendidikan; (2) Setiap warga negara wajib mengikuti pendidikan dasar dan pemerintah wajib membiayainya; serta (3) Pemerintah mengusahakan dan menyelenggarakan satu sistem pendidikan nasional yang meningkatkan keimanan dan ketakwaan serta akhlak mulia dalam rangka mencerdaskan kehidupan bangsa.

Mencermati betapa pentingnya peranan guru dalam mencerdaskan kehidupan bangsa dengan meningkatkan pendidikan yang berkualitas sebagaimana ditegaskan dalam Pasal 1 ayat 1 Undang-Undang Republik Indonesia Nomor 20 Tahun 2003 tentang 
Sistem Pendidikan Nasional, bahwa pendidikan adalah usaha sadar dan terencana untuk mewujudkan suasana belajar dan proses pembelajaran agar peserta didik secara aktif mengembangkan potensi dirinya untuk memiliki kekuatan spiritual keagamaan, pengendalian diri, kepribadian, kecerdasan, akhlak mulia, serta ketrampilan yang diperlukan dirinya, masyarakat, bangsa dan negara. Untuk itu pemerintah berkewajiban untuk mengusahakan dan menyelenggarakan satu sistem pendidikan nasional yang meningkatkan keimanan dan ketakwaan kepada Tuhan Yang Maha Esa serta akhlak mulia dalam rangka mencerdaskan kehidupan bangsa yang diatur dengan undang-undang, sitem pendidikan nasional yang dimaksud tersebut harus mampu menjamin relevansi dan efesiensi manajemen pendidikan untuk menghadapi tantangan sesuai dengan tuntutan perubahan kehidupan lokal, nasional, dan global sehingga perlu diselenggarakan pendidikan secara terencana, terarah dan berkesinambungan.

Dalam mengusahakan dan menyelenggarakan satu sistem pendidikan nasional tersebut, yang menjadi ujung tombak atau tingkat terbawah dan terdepan yang langsung berhadapan dengan peserta didik adalah tenaga pendidik. Dengan demikian pada pelaksanaan pembelajaran di kelas, pendidik sangat berperan dalam membawa peserta didiknya ke arah pembelajaran yang disyaratkan dalam kurikulum.

Pembelajaran yang disyaratkan dalam kurikulum di antaranya dalam penilaian hasil belajar pada sutuan pendidikan berdasarkan panduan kurikulum 2013 revisi (K13 revisi) diamanatkan bahwa siswa boleh naik kelas apabila telah mencapai kreteria ketuntasan minimal (KKM) setiap mata pelajaran sebagaimana yang ditetapkan oleh satuan pendidikan masing-masing, dan bagi siswa yang tidak mencapai KKM tersebut harus mengikuti program remedial yang dilaksanakan oleh guru pengampu mata pelajaran yang bersangkutan. Dalam proses inilah keprofesionalan tenaga pendidik diuji dan oleh karena itu pendidik harus secara terus menerus memperkaya dirinya dengan ilmu pengetahuan, dengan demikian tenaga pendidikan yang profesinal harus mampu mengikuti perkembangan zaman dan perkembangan peserta didiknya.
Pada perkembangannya pengakuan dan kedudukan pendidik sebagai tenaga profesional pada jenjang pendidikan dari jenjang dasar, pendidikan menengah dan pendidikan anak pada usia dini pada pendidikan formal dibuktikan dengan sertifikat pendidik, yang merupakan bukti formal pengakuan kepada pendidik sebagai tenaga formal. Pada dasarnya sertifikasi pendidik merupakan salah satu upaya untuk meningkatkan martabat dan peran pendidik sebagai agen pembelajaran, dengan terlaksananya sertifikasi pendidik ini, diharapkan akan berdampak pada meningkatnya mutu pembelajaran dan mutu pendidikan secara berkelanjutan.

Harapan dampak sertifikasi pada meningkatnya mutu pembelajaran dan mutu pendidikan secara berkelanjutan bukan hal yang berlebihan, karena pendidik yang lulus sertifikasi melalai jalur penilaian protofolio secara obyektif menunjukkan bahwa pendidik tersebut benar-benar tenaga pendidik yang profesional, dan dalam proses perjalanan berikutnya yang kemudian ditemukan indikasi ketidak jujuran oknum pendidik dalam proses pengajuan penilian protofolio tidak seharusnya mempengaruhi sikap guru yang benar-benar profesional. Pendidik yang profesional tidak akan pernah memperhitungan berapa imbalan yang akan diterimanya, tetapi bagaimana dalam segala keterbatasan dapat mencerdaskan anak bangsa.

Menurut Veithzal Rivai dan Sylviana Murni ${ }^{1}$, profesionalisme pendidik dapat dilihat dalam kompetensi atas tiga bidang kelompok, yaitu bidang keahlian atau keilmuan, bidang pembelajaran, dan bidang kepribadian. Secara umum profesionalitas itu terwujud dalam penguasaan bahan acar secara benar dan tepat dalam menyampaikan bahan pelajaran kepada siswa sehingga siswa semakin mau belajar dan menjadi berkompeten. Pendidik juga diharapkan mengembangkan kepribadiannya sebagai pengajar dan pendidik yang bertanggung jawab, yang mengerti keadaan siswa, dan dapat berkomunikasi secara baik dengan siswa. Sebab, guru juga menjadi teladan dalam hal nilai kehidupan. Dalam praktik di lapangan, masih banyak guru yang

${ }^{1}$ H. Veithzal Rivai dan Hj. Sylviana Murni, Education Management Analisis Teori dan Praktik, (Jakarta: Rajawali Pers, 2010), h. 898. 
tidak dapat menjadi teladan kehidupan bagi siswanya. Di sinilah kepribadian pendidik harus dikembangkan sehingga dapat berprofesi sebagai pendidik yang profesional.

Pengembangan profesi pendidik sangat penting artinya dalam rangka peningkatan mutu pendidikan, terlebih melihat kondisi saat ini. Terutama yang berkaitan dengan berbagai hal yang ditemui dalam melaksanakan pendidikan, yaitu perkembangan iptek, dan persaingan global bagi lulusan pendidikan.

Dengan demikian jelas bahwa dalam pengembangan kemampuan pendidik dalam melaksanakan tugas, fungsi dan perannya, merupakan suatu kebutuhan yang mendesak. Ini merupakan konsekuensi dari profesi yang menuntut harus dilaksanakan secara profesional. Dan kita menyadari bahwa adanya keterbatasan yang ada pada diri manusia karena kita bukan makhluk yang serba bisa dan membutuhkan pengalaman atau pengetahuan baru untuk dapat menjadi lebih bisa walaupun belum sempurna. Hal ini sejalan dengan pengertian dari Pengembangan Keprofesian Berkelanjutan (PKB), yang terdapat dalam buku Pedoman Pengelolaan PKB yang diterbitkan oleh Kementerian Pendidikan Nasional tahun 2011, bahwa PKB adalah bentuk pembelajaran berkelanjutan bagi guru yang merupakan kendaraan utama dalam upaya membawa perubahan yang diinginkan berkaitan dengan keberhasilan siswa.

Dengan demikian semua siswa diharapkan dapat mempunyai pengetahuan lebih, mempunyai ketrampilan lebih baik, dan menunjukkan pemahaman yang mendalam tentang materi ajar serta mampu memperlihatkan apa yang mereka ketahui dan mampu melaksanakan. PKB mencakup berbagai cara dan/atau pendekatan di mana guru secara berkesinambungan belajar setelah memperoleh pendidikan dan/atau pelatihan awal sebagai pendidik. PKB mendorong pendidik untuk memelihara dan meningkatkan standar mereka secara keseluruhan mencakup bidang-bidang berkaitan dengan pekerjaannya sebagai profesi.

Selanjutnya para pendidik dapat memelihara, meningkatkan serta memperluas pengetahuan dan ketrampilannya serta membangun kualitas pribadi yang dibutuhkan di dalam kehidupan profesionalnya.
Mengingat pentingnya PKB ini Daryanto dan Tasrial ${ }^{2}$ menyebutkan bahwa salah satu hal yang sangat penting adalah program PKB harus membentuk komitmen yang tinggi dan terus menerus terjaga pada diri setiap pendidik untuk menjadi pendidik yang profesional. Komitmen ini akan menyadarkan kepada guru untuk terus berkembang dan memperbaiki diri menghadapi berbagai tantangan dan tuntutan di masa depan terkait dengan tugas dan kewajibannya dengan pendidik. Dan terlebih penting lagi tercapainya guru profesional sebagai salah satu upaya untuk mencerdaskan kehidupan bangsa tidak hanya bergantung pada program PKB ataupun komitmen para pendidik itu sendiri, namun semua pihak yang terlibat dalam pendidikan harus mendukung dan memberikan konstribusi sesuai dengan tugas, tanggung jawab dan wewenangnya.

Berdasarkan perkembangan di lapangan terdapat kendala dalam mencapai guru profesional di antaranya adalah keluhan terhadap lulusan pendidikan guru yang kurang dalam penguasaan bidang ilmu dan kurang profesional mengajar di kelas. Masih ada pendidik tidak menguasai bahan yang diajarkan dan mengajarkan secara salah, dan ada juga yang belum kompeten dalam mengajarkan bahan pelajaran kepada siswa. Beberapa pendidik takut dan grogi berdiri di depan kelas sehingga proses belajar mengajar menjadi kacau. Dan di antara para guru kurang mampu menyikapi siswa-siswa yang sering mengganggu, sehingga yang bersangkutan jarang masuk mengajar di kelas.

Mengingat pentingnya pendidikan dalam mencerdaskan kehidupan bangsa, maka Dinas Pendidikan Kota/Kabupaten harus aktif dalam mengatasi kendala tersebut. Dinas Pendidikan Kota/Kabupaten sebagai organisasi pendidikan tertinggi di wilayah kota/kabupaten secara manajerial memegang peranan yang sangat penting dalam memberikan solusi dalam menyelesaikan atau memberikan jalan keluar terhadap kendala tersebut. Di antara solusi yang dapat diambil yaitu dengan memprogramkan peningkatan kompetensi pendidik dalam bidang ilmu pengetahuan dan pembelajaran melalui pengembangan keprofesian berkelanjutan (PKB) dengan

${ }^{2}$ Daryanto dan Tasrial, Pengembangan Karir Profesi Guru (Yogyakarta: Gava Media, 2015), h. 168. 
mengindahkan fungsi manajemen personalia atau pendidik.

Pengembangan profesi merupakan salah satu unsur yang dipersyarakatkan dalam Peraturan Menteri tersebut adalah untuk kenaikan pangkat yang lebih tinggi, dari golongan ruang $\mathrm{IV} / \mathrm{a}$ ke $\mathrm{IV} / \mathrm{b}$ dengan diwajibkan sekurang-kurangnya mengumpulkan 12 (dua belas) angka kredit dari unsur pengembangan profesi tersebut. Kesulitan mengumpulkan 12 (dua belas) angka kredit dari unsur pengembangan profesi inilah sehingga timbul kesenjangan atau penumpukan pendidik dengan pangakat golongan ruang IV/a dengan pendidik yang dapat naik golongan ruang IV/b.

Kesenjangan ini menjadi sangat menarik untuk diteliti karena Pendidik SMP golongan IV/a merupakan Pendidik Profesional yang sudah bersertifikasi. Dengan terhentinya pangkat golongan ruang Pendidik SMP pada golongan IV/a maka seakan-akan kenaikan pangkat menjadi terhenti. Di lain pihak pengembangan profesi Tenaga Pendidik SMP pada Dinas Pendidikan dan Kebudayaan Kabupaten Kutai Barat sebagai bagian integral dalam pendidikan dasar 9 (sembilan) tahun menjadi sangat urgen. Sebagai Pendidik SMP yang subah bersrtifikat Pendidik, tentu telah melewati seleksi yang sangat ketat, dan menjalani Pendidikan dan Latihan Profesi pendidik, dalam rangka pengembangan profesi pendidik.

Kesenjangan inilah yang membuat kegelisahan penulis, sehingga penulis tertarik untuk melakukan penenelitian tentang pengembangan profesi Tenaga Pendidik SMP pada Dinas Pendidikan dan Kebudayaan Kabupaten Kutai Barat.

Penelitian ini untuk mengkaji bagaimana pengembangan profesi tenaga pendidik SMP pada Dinas Pendidikan dan Kebudayaan Kabupaten Kutai Barat, dengan rumusan masalah sebagai berikut :

1. Bagaimana kebijakan dalam perencanaan program pengembangan profesi tenaga pendidik SMP pada Dinas Pendidikan dan Kebudayaan Kabupaten Kutai Barat dikaji dari :

2. Bagaimana pelaksanaan program pengembangan profesi tenaga pendidik SMP pada Dinas Pendidikan dan Kebudayaan Kabupaten Kutai Barat

3. Bagaimana hasil pelaksanaan program pengembangan profesi tenaga pendidik
SMP pada Dinas Pendidikan dan Kebudayaan Kabupaten Kutai Barat

\section{Metode Penelitian}

Metode yang digunakan dalam penelitian adalah deskriptif kualitatif yang bertujuan untuk menghasilkan data dengan analisis deskriptif kualitatif yang menggambarkan keadaan pengembangan profesi pendidik SMP pada Dinas Pendidikan Kabupaten Kutai Barat. Pengumpulan data dalam penelitian ini dilakukan dengan observasi partisipan atau pengamatan berperanserta, dokumentasi dan wawancara dengan Kepala Dinas Pendidikan, Sekretaris Dinas Pendidikan, Kepala Sub Bagian Perencanaan Program, Kepala Sub Bagian Keuangan, Kepala Bidang Pembinaan Ketenagaan, Kepala Seksi PTK Pendidikan Dasar dan Ketua Pengawas SMP sebagai informan utama, sedangkan informan pendukungnya adalah Kepala SMPN 2 Sendawar Barong Tongkok dengan 2 orang pendidiknya, Kepala SMPN 1 Sendawar Melak dengan 2 orang pendidiknya, SMPN 1 Linggang Bigung dengan 2 orang pendidiknya, Kepala SMPN 1 Long Iram dengan 2 orang pendidiknya, dan Kepala SMPN 2 Bongan dengan 2 orang pendidiknya.

Data yang peroleh divalidasi untuk memperoleh keabsahan data dengan teknik pemeriksaan berdasarkan empat kreteria yaitu (1) derajat kepercayaan (credibility), (2) keteralihan (confirmability), (3) kebergantungan (dependability), dan (4) kepastian (confirmability). Selanjutnya data dianalisis dengan menggunakan analisis kualitatif melalui tiga tahapan, yaitu (1) reduksi data (data reduction); (2) paparan data (data display); dan (3) penarikan kesimpulan dan verifikasi (conclusion drawinglverifying).

\section{Hasil Penelitian dan Pembahasan}

Perencanaan Pengembangan Profesi Pendidik SMP pada Dinas Pendidikan dan Kebudayaan Kabupaten Kutai Barat. telah mempertimbangkan unsur-unsur manajemen $7 \mathrm{M}$, yaitu man, money, material, machines, methods, marketing, dan minutes.

Pelaksanaan Pengembangan Profesi Pendidik SMP pada Dinas Pendidikan dan Kebudayaan Kabupaten Kutai Barat dengan mempertimbangkan unsur-unsur manajemen 7M, yaitu man, money, material, machines, 
methods, marketing, dan minutes, sebagai berikut :

1. Keterlibatan pihak-pihak yang berkompeten dalam pengembangan profesi pendidik SMP Dinas Pendidikan dan Kebudayaan Kabupaten Kutai Barat tampak sebagai satu tim yang solid dalam tenaga kependidikan yang meliputi, Kepala Dinas Pendidikan, Sekretaris, Kepala Sub Bagian Keuangan, Kepala Sub Bagian Keuangan, Kepala Bidang Ketenagaan, Kepala Seksi PTK Pendidikan Dasar, dan Pengawas SMP, dan untuk nara sumbernya melibatkan Widyaswara dari LPMP, dosen Universitas Mulawarman, Instruktur Provinsi (IP), dan Instruktur Kabupaten (IK).

2. Biaya atau dana yang dipergunakan untuk pengembangan profesi pendidik SMP Dinas Pendidikan dan Kebudayaan Kabupaten Kutai Barat yang berasal dari APBN berupa bantuan Blockgrant melalui LPMP, dan APBD, serta di sekolah melalui dana BOS (Bantuan Operasioal Sekolah), sangat sesuai sistem Blockgrant yang beracuan pada mutu atau merit based competition juga bentuk peningkatan anggaran yang lain.

3. Fasilitas atau tempat yang dipergunakan untuk pelatihan dalam rangka pengembangan profesi pendidik SMP adalah Ruang Rapat Dinas Pendidikan dan Kebudayaan, kalau pesertanya banyak dapat menggunakan Balai Pertemuan Umum Kabupaten baik di BPU Tana Purai Ngeriman atau Aji Tulur Jejangkat, kemudian di Aula Sekolah baik Aula SMP Negeri 1 Sendawar di Melak atau SMP Negeri 2 Sendawar di Barong Tongkok, dan untuk SMP yang belum memiliki Aula dapat menggunakan ruang kelas untuk melaksanakan Pelatihan atau In House Training.

4. Material, atat-atat atau media yang dioergunakan dalam pengembangan profesi pendidik SMP Dinas Pendidikan dan Kebudayaan Kabupaten Kutai Barat, adalah pengeras suara atau Sound System, In Fokus, Laptop, Papan Tulis, Buku Panduan, dan kertas metaplan.

5. Methods, metode yang digunakan dalam pelaksanaan kebijakan pengembangan profesi pendidik SMP Dinas Pendidikan dan Kebudayaan Kabupaten Kutai Barat, adalah melalui Sosialisasi, Pelatihan, In House Training, Workshoap, Workshop ini kegiatannya untuk menyusun Dokumen I K13 serta Dokumen II K13, Kegiatan MGMP dan lain sebagainya.

6. Market, peserta yang diundang dalam pelaksanaan kebijakan pengembangan profesi pendidik SMP Dinas Pendidikan dan Kebudayaan Kabupaten Kutai Barat, adalah Pendidik SD, SMP, SMA dan SMK mulai Golongan II, Golongan III sampai Golongan IV, namun dapat juga khusus untuk pendidik SMP yang golongan IVa, sedangkan untuk pendidik Paud ada kegiatannya tersendiri.

7. Minutes, waktu hari pelaksanaan kegiatan pengembangan profesI pendidik SMP, dilaksanakan dengan tidak mengganggu jam atau aktivitas belajar mengajar di sekolah, yaitu pada setiap minggu atau di setiap bulan itu berdasarkan kesepakatan sekolah bersama-sama dengan dinas pendidikan yang telah menentukan waktu yang cocok untuk dilakukan pelaksanaan pelatihan itu, pada masa libur sekolah

Karena keterbatasan anggaran pada Dinas Pendidikan dan Kebudayaan Kabupaten Kutai Barat, ada pendidik SMP yang mengikuti pengembangan profesi dengan biaya mandiri, misalnya meningkatkan kualifikasi pendidikan dari D III ke S1, dan dari S1 ke S2, ada juga yang mengikuti Diklat, Seminar, dan Workshop. Dan sebagai contohnya baru-baru ini di Samarinda ada Workshop penyusunan Kurikulum Lalu Lintas yang diimplementasikan dalam mata pelajaran PPKN, ini pendidik-pendidik terutama Guru PPKN itu mengikuti Workshop tersebut dengan biaya sendiri.

Pengembangan profesi pendidik SMP juga diselenggarakan oleh sekolah masingmasing dengan menyelenggarakan pendidikan dan pelatihan berupa In House Training, Workshop, dan MGMP. Dengan materi pokok pengembagan diri serta membuat publikasi ilmiah dan atau karya inovatif, khususnya Penelitian Tindakan Kelas (PTK) bagi pendidik SMP.

Pengawas SMP selain sebagai pengisi atau pemateri pada kegiatan sosialisasi, bimbingan teknis atau pelatihan yang diselenggaran oleh Dinas Pendidikan Kabupaten/Kota atau Satuan Pendidikan (sekolah) juga sebagai pembimbing dan pelatih profesi guru atau pendidik yang 
berhubungan dengan pengembangan profesi pendidik SMP, dengan memberikan layanan pribadi atau "personal service". Personal Service ini terutama dalam hal Penyusuanan Usulan Penetapan Angka Kredit Guru, khususnya pada bagian sub penilain pengembangan profesi atau pengembangan profesi berkelanjutan. Layanan pribadi tersebut di atas pada saat seorang pendidik SMP mengalami kesulitan dalam mensinkronkan antara Sasaran Kerja Pegawai (SKP) dengan Usulan Penetapan Angka Kredit (PAK) kenaikan pangkat yang bersangkutan, dalam Sub Pengembangan Profesi atau Pengembangan Profesi berkelanjutan yang diusulkan harus termuat dalam Sasaran Kerja Pegawai atau SKP.

Pengembangan Profesi Pendidik SMP pada Dinas Kabupaten Kutai Barat yang berhubungan erat dengan kenaikan pangkat/golongan tertinggi yang dicapai oleh Pendidik SMP menunjukan bahwa dari 320 orang Pendidik SMPN sebanyak 95 orang atau $29,69 \%$ Golongan IVa dan 13 orang atau $4,06 \%$ telah mencapai Golongan IVb.

\section{Kesimpulan}

Dari hasil penelitian dan pembahasan pada bab sebelumnya mengenai pengembangan profesi tenaga pendidik SMP pada Dinas Pendidikan dan Kebudayaan Kabupaten Kutai Barat dapat disimpulkan bahwa pengembangan profesi tenaga pendidik SMP pada Dinas Pendidikan dan Kebudayaan Kabupaten Kutai Barat meliputi Perencanaan Pengembangan Profesi Pendidik SMP pada Dinas Pendidikan dan Kebudayaan Kabupaten Kutai Barat. telah mempertimbangkan unsur-unsur manajemen $7 \mathrm{M}$, yaitu man, money, material, machines, methods, marketing, dan minutes. Pelaksanaan Pengembangan Profesi Pendidik SMP pada Dinas Pendidikan dan Kebudayaan Kabupaten Kutai Barat dengan mempertimbangkan unsurunsur manajemen 7M. Pengembangan Profesi Pendidik SMP pada Dinas Kabupaten Kutai Barat yang berhubungan erat dengan kenaikan pangkat/golongan tertinggi yang dicapai oleh Pendidik SMP menunjukan bahwa dari 320 orang Pendidik SMP sebanyak 95 orang atau $29,69 \%$ Golongan IVa dan 13 orang atau $4,06 \%$ telah mencapai Golongan IVb. Rekomendasi agar Dinas Pendidikan dan Kebudayaan Kabupaten Kutai Barat, dapat meningkatkan intensitas dan kualitas pengembangan profesi Pendidik SMP di wilayah kerjanya dengan meningkatkan anggaran serta kerjasama dengan pihak-pihak yang berkompeten seperti LPMP dan LPTK khususnya dari Fakultas Keguruan dan Ilmu Pendidikan, Universitas Mulawarman sebagai LPTK terdekat dan tertua di Provinsi Kalimantan Timur, dengan materi pokok pengembagan diri serta membuat publikasi ilmiah dan atau karya inovatif, khususnya Penelitian Tindakan Kelas (PTK) bagi pendidik SMP.

\section{Daftar Pustaka}

Alma, H. Buchari. dkk. Guru Profesional Menguasai Metode dan Terampil Mengajar, Bandung: Alfabeta, 2010.

Amtu, Onisimus. Membenahi Pendidikan di Wilayah Kepulauan, Bandung: Alfabeta, 2014.

Arikunto, Suharsimi. Prosedur Penelitian Suatu Pendekatan Praktik, Jakarta: Rineka Cipta, 2010.

Barizi, Ahmad dan Muhammad Idris. Menjadi Guru Unggul Bagaimana Menciptakan Pembelajaran yang Produktif \& Profesional, Yogyakarta: Ar-Ruzz Media, 2010.

Bungin, Burhan. (Ed.). Analisis Data Penelitian Kualitatif, Jakarta: Raja Grafindo Persada, 2011.

Bungin, Burhan. Metodologi Penelitian Kualitatif, Jakarta: RajaGrafindo Persada, 2011.

Daryanto dan Tasrial, Pengembangan Karir Profesi Guru, Yogyakarta: Gava Media, 2015.

Depdiknas, Kamus Besar Bahasa Indonesia Edisi Ketiga, Jakarta: Balai Pustaka, 2001.

Gunawan, Imam. Metode Penelitian Kualitatif Teori \& Praktik, Jakarta: Bumi Aksara, 2015.

Kartono, Kartini. Pengantar Metodologi Riset Sosial, Bandung: Mandar Maju, 1990.

Kinchelo, Joe L. Guru Sebagai Peneliti Pemberdayaan Mutu Guru dengan Metode Panduan Penelitian Kualitatif terjemahan Nasir Syar'an. Yogyakarta: IRCiSoD, 2014.

Makawimbang, Jerry H. Supervisi dan Peningkatan Mutu Pendidikan, Bandung: Alfabeta, 2011. 
Hayes Mizell, “Why Professional Development Matter, Locust St. Oxford: Learning Forward, 2010.

https://learningforward.org (diakses 1 April 2017)

Moleong, Lexy J. Metodologi Penelitian Kualitatif, Bandung, Remaja Rosdakarya, 2011.

Mulyasa. Standar Kompetensi dan Sertifikasi Guru, Bandung: Remaja Rosdakarya, 2013.

Prastowo, Andi. Metode Penelitian dalam Perspektif Rancangan Penelitian, Yogyakarta: Ar-Ruzz Media, 2011

Rachmah, Huriah. Pengembangan Pendidikan IPS, Bandung: Alfabeta, 2014.

Rachmawati, Tutik dan Daryanto. Penilaian Kinerja Guru dan Angka Kreditnya, Yogyakarat: Gava Media, 2013.

Rahman, Muhammat dan Sofan Anri, Kode Etik Profesi Guru, Jakarta: Prestasi Pustaka, 2014.

Rivai, Veithzal. Education Management Analisis Teori dan Praktik, Jakarta: Rajawali Pers, 2010.

Rusdiana, H. A. dan $\mathrm{Hj}$. Yeti Heryati. Pendidikan Profesi Keguruan Menjadi Guru Inspiratif dan Inovatif, Bandung: Pustaka Setia, 2015.

Rusman. Seri Manajemen Sekolah Bermutu Model-Model Pembelajaran Mengembangkan Profesionalisme Guru, Jakarta: Rajawali Pers, 2011.

Saondi, Ondi dan Aris Suherman. Etika Profesi Keguruan, Bandung: Refika Aditama, 2012.

Saud, Udin Syaefudin. Pengembangan Profesi Guru, Bandung Alfabeta, 2013.

Soetjipto dan Raflis Kosasi, Profesi Keguruan, Jakarta: Rineka Cipta, 2011.

Suyanto dan Asep Djihad, Bagaimana Menjadi Calon Guru dan Guru Profesional, Yogyakarta: Multi Pressindo, 2013.

Suryosubroto, B. Manajemen Pendidikan di Sekolah, Jakarta: Rineka Cipta, 2010.
Uno, H. Hamzah B. Profesi Kependidikan Problema, Solusi, dan Reformasi Pendidikan di Indonesia, Jakarta: Bumi Aksara, 2014.

Usman, Husaini. Manajemen Teori Praktik \& Riset Pendidikan, Jakarta: Bumi Aksara, 2008.

Usman, Moh. Uzer. Menjadi Guru Profesional, Bandung: Remaja Rosdakarya, 2000.

Wiyani, Novan Ardi. Etika Profesi Keguruan, Yogyakarta, Gava Media, 2015. Kebijakan Pengembangan Profesi Guru, Jakarta: Kementrian Pendidikan dan Kebudayaan, 2012. , Undang-Undang Dasar 1945 (Amandemen), Yogyakarta: Pustaka Yustisia, 2003. Undang-Undang Republik Indonesia Nomor 20 Tahun 2003 Tentang Sistem Pendidikan Nasional, Bandung: Fokusmedia, 2003.

https//:pdfs.semanticscholar.org/008c/46ae73f 568a44d7120f208edbdc15ee2a4.pdf (diakses 1 April 2017)

http://publikasipendidikan.blogspot.co.id/2012 /07/manajemen-pengembanganprofesi-guru.html (diakses 1 April 2017)

http://pu.edu.pk/images/journal/JEE/PDFFiles/4_v25_no1_15.pdf (diakses 1 April 2017)

http://www.cie.org.uk/images/271194professional-development.pdf (diakses 1 April 2017)

https://www.careers.govt.nz/practitioners/care er-practice/career-theory-models/ (diakses 1 April 2017)

http://www.educ.cam.ac.uk/people/staff/watso n/Watson_CERME8 2013_Proceedin gs.pdf (diakses 1 April 2017)

http://doc.utwente.nl/87901/1/evaluating a pd $\mathrm{p}$ for impl_mss JETS.pdf (diakses 1 April 2017)

http://edepot.wur.nl/265369.html (diakses 1 April 2017) 